\title{
STRATEGI PENANGANAN PERILAKU MENYIMPANG PESERTA DIDIK MELALUI GURU SEBAGAI ROLE MODEL
}

\author{
Endang Setyowati \\ Program Studi Pendidikan Bahasa dan Sastra Indonesia \\ IKIP Budi Utomo Malang \\ Jalan Citandui 46 Malang \\ e.setyowati83@yahoo.com \\ Dwi Ulfa Nurdahlia \\ Program Studi Pendidikan Bahasa dan Sastra Indonesia \\ IKIP Budi Utomo Malang \\ Jalan Citandui 46 Malang \\ dwiulfan@gmail.com
}

\begin{abstract}
Deviant behavior is defined as behavior, actions, or someone in response to the environment contrary to the norms and laws that exist in society. Amid public life still occasionally encountered measures are not in accordance with the rules (norms) in effect on the community, for example a students cheat on quizzes, lying, stealing, and disturbing other students. Spot, the role of teachers is necessary and can be done through education and will appear, when the teacher managed to create a positive character on learners, for example learners will be an honest individual (not cheating on replay, lying, stealing) and disturbing other students. Therefore, teachers become good role models, pay attention to several criteria such as: having a good personality, including how to speak, how to relate with learners, behavior, etchics are high, kind, friendly, trustworthy, resolute, sincerity in teaching, course of action tat leads to a positive attitude and so on.
\end{abstract}

Keyword: deviant behavior, the teacher as an educator, role model

Perilaku menyimpang yang juga biasa dikenal dengan nama penyimpangan sosial adalah perilaku yang tidak sesuai dengan nilainilai kesusilaan atau kepatutan, baik dalam sudut pandang kemanusiaan (agama) secara individu maupun pembenarannya sebagai bagian daripada makhluk sosial.Perilaku abnormal biasa dipelajari dalam ilmu psikologi. Psikologi abnormal (abnormal psychology) merupakan salah satu cabang psikologi yang berupaya untuk memahami pola perilaku abnormal dan cara menolong orang-orang yang mengalaminya (Greene, dkk, 2005). Beberapa kriteria untuk menentukan abnormal (Greene, dkk, 2005): perilaku yang tidak biasa, perilaku yang tidak dapat ditermia secara sosial atau melanggar norma sosial, persepsi atau interpretasi yang salah terhadap realitas, orangorang tersebut berada dalam stress personal yang signifikan, perilaku maladaptif atau self defeating, perilaku berbahaya. Dalam Kamus Besar Bahasa Indonesia perilaku menyimpang diartikan sebagai tingkah laku, perbuatan, atau tanggapan seseorang terhadap lingkungan yang bertentangan dengan norma-norma dan hukum yang ada di dalam masyarakat.

Dalam kehidupan masyarakat, semua tindakanmanusia dibatasi oleh aturan (norma) untuk berbuat dan berperilaku sesuai dengan sesuatu yang dianggap baik oleh masyarakat. Namun di tengah kehidupan masyarakat kadang-kadang masih kita jumpai tindakantindakan yang tidak sesuai dengan aturan (norma) yang berlaku pada masyarakat, misalnya seorang siswa menyontek pada saat ulangan, berbohong, mencuri, dan mengganggu siswa lain.

Hal diatas dipengaruhi oleh berbagai faktor antara lain dampak dari modernisasi dan globalisasi yang mengakibatkan etika dan moral peserta didik semakin tidak terarah.Modernisasi dan globalisasi dapat masuk ke kehidupan peserta didik melalui berbagai media, terutama media elektronik seperti internet.Karena dengan fasilitas ini semua orang dapat dengan bebas mengakses informasi dari berbagai belahan 
dunia.Pengetahuan dan kesadaran seseorang peserta didik sangat menentukan sikapnya untuk menyaring informasi yang didapat. Untuk itu, diperlukan peranan guru sebagai role model dalam sekolah. Model merupakan rencana keseluruan, atau pola, guna membantu peserta didik mempelajari jenis pengetahuan, sikap, atau keterampilan khusus (Arends, 2013).

\section{PEMBAHASAN}

\section{Peranan Guru sebagai Pendidik}

Guru merupakan salah satu stake holder yang memiliki peranan penting dalam dunia pendidikan. Mereka adalah salah satu tonggak pendidikan yang siap untuk mentransfer ilmu yang kelak akan menjamin masa depan dari peserta didik. Berdasar istilah yang ada di Jawa, soko guru.Soko berarti tiang, dan guru berarti utama (Aqib, 2010).Dengan kata lain, guru merupakan penyangga dalam dunia pendidikan. Ketika tiang penyangga kokoh, maka bangunan dalam dunia pendidikan akan kokoh. Peranan guru melalui pendidikan akan tampak, ketika guru berhasil menciptakan karakter positif pada peserta didik, misal peserta didik akan menjadi individu yang jujur (tidak menyontek saat ulangan, berbohong, mencuri) dan mengganggu siswa lain.

Berikut penulis akan mencoba mengembangkan peranan guru yang ditinjau dari sebuah buku yang berjudul Berguru ke Matahari yang ditulis oleh Andreas Hareva yang terdiri dari 8 poin utama (dalam Aqib, 2010) yaitu seorang guru/ pemimpin itu dapat disimbolkan dengan watak delapan benda langit, yaitu:

(1) Matahari yang menumbuhkan daya hidup yang dipimpin

Ketika matahari menjadi poros yang memberikan kehidupan bagi yang dipimpin, yaitu peserta didik.Maka guru harus mampu memberikan cahaya yang mampu menunjukkan dan memberikan bimbingan untuk membentuk karakter positif bagi peserta didik.

\section{Sebuah sekolah yang berada di kantor wilayah sekolah Portland} meluncurkan program pendidikan moral yang berpusat pada enam nilai nonkontroversial: rasa hormat, keberanian, keadilan, kemauan untuk bekerja, dan disiplin diri. Masing-masing sekolah bertugas untuk menyisipkan nilai moral ini dengan cara apa pun yang dapat dilakukan melalui kurikulum dan kegiatan sehari-hari.

Sumber:Lickona, 2012

Jika bentuk penanaman moral sudah dimasukkan dalam kurikulum, maka guru harus memasukkan dalam materi pembelajaran berikut beberapa mata pelajaran yang dicontohkan dalam program pendidikan moral di Portland: 
Kotak 2. Penanaman Karakter melalui Mata Pelajaran

- Matematika dan sains: guru dapat memusatkan perhatian pada orang-orang terkemuka dalam berbagai bidang. Sebagai, tambahan metodologi yang sangat terstruktur dan berdisiplin yang ditemukan dalam kedua mata pelajaran dapat juga ditekankan.

- Bahasa Inggris: guru dapat menggambarkan contoh disiplin diri studi literatur. Murid-murid dapat diminta untuk menuliskan karangan mengenai sifat yang penting ini.

- Sejarah: guru dapat mengarahkan perhatian pada momen-momen tertentu dalam sejarah, dimana orang-orang terkemuka menunjukkan sikap disiplin.

- Kesenian dan music: instruktur dapat membedah kehidupan artis dan composer terkemuka sebagai contoh sikap disiplin diri.

- Ekonomi rumah tangga dan seni industry: guru dapat menekankan pentingnya disiplin diri dalam merancang dan menciptakan bendabenda kayu, metal, pakaian, dan lain-lain.

- Ilmu kesehatan dan jasmani: guru dapat mengarahkan pada siswa bahwa manusia harus memiliki disiplin diri untuk dapat mempertahankan kesehatan tubuh.

Sumber:Lickona, 2012

Mata pelajaran diatas dapat digunakan sebagai rujukan para guru yang ada di Indonesia sebagai pandangan untuk mengembangkan penanaman nilai karakter. Melalui pembelajaran di kelas akan memberikan cahaya bagi peserta didik untuk memiliki karakter positif. Hal ini, dapat membantu peserta didik tidak hanya memiliki pemahaman secara akademik, melainkan peserta didik akan mendapatkan nilai moral.

(2) Bulan yang lembut dan penuh harapan Sebagian besar peserta didik sangat menyukai guru yang lembut dan selalu menumbuhkan harapan.Sikap ini dimunculkan dalam pelaksanaan pembelajaran. Oleh karena itu dibutuhkan keterampilan mengajar (Djiwandono, 2004), meliputi: menyampaikan dan menjelaskan mata pelajaran, mendengarkan, memperkenalkan mendemonstrasikan, memperoleh respons dari siswa, dan menutup. Melalui kemampuan keterampilan ini, akan memberikan kemudahan bagi guru untuk menanamkan nilai-nilai moral yang akan membentuk karakter peserta didik.Kemampuan mengkompilasi materi dan penanaman moral secara laten dalam pembelajaran akan membuat peserta didik merasa tidak digurui atau dipaksa untuk memiliki karakter yang kemungkinan belum mereka terima atau mungkin adanya nilai yang kontra dengan nilai yang dimiliki oleh peserta didik.

(3) Bintang yang menjadi teladan dan pedoman dalam kehidupan

Menjadi seorang bintang merupakan kebahagiaan bagi seorang guru. Sosok yang akan menjadi sorotanoleh peserta didik, tidak hanya penampilan secara fisik, melainkan termasuk tingkah laku dan karakter yang dimiliki oleh seorang guru.Misal, peserta didik akan menilai seorang guru dari tingkah laku dan tutur kata yang ditunjukkan oleh guru. Guru yang berkarakter positif memiliki kemampuan untuk menunjukkan perilaku dan tutur kata secara spontan. Sehingga, peserta didik akan melihat sosok guru yang berkarakter kuat. Seorang penulis buku Quantum Teaching, menyatakan bahwa keteladanan, ketulusan, kongruensi, dan kesiapsiagaan Anda akan 
memberdayakan dan mengilhami peserta didik untuk membebaskan potensi mereka sebagai pelajar (DePorter, 2000). Pada dasarnya, peserta didik merupakan individu yang memiliki potensi untuk mengembangkan diri.

(4) Langit yang berjiwa besar

Bagi seorang pendidik sepatutnya menjadi langit yang memiliki ruang yang luas untuk berjiwa besar.Sebab, keputusan untuk berperan dalam dunia pendidikan merupakan keputusan yang siap untuk menerima segala konsekuensi dalam duni pendidikan. Termasuk, konsekuensi untuk menerima peserta didik apa adanya. Peserta didik merupakan individu yang unik dengan segala potensi yang bisa dikembangkan. Guru memiliki peran dalam mengembangkan potensi yang beraneka ragam. Selayaknya seorang guru, tidaklah diizinkan untuk memaksakan kehendak guru dalam mengembangkan diri peserta didik.Sehingga, perlu adanya ruang dalam mengembangkan potensi peserta didik. Hal ini sesuai dengan teori Maslow tentang level tertinggi kebutuhan manusia adalah aktualisasi diri (Feist, 2012).Aktulisasi peserta didik akan berkembang, saat mereka memiliki keyakinan dan tentunya dukungan dari guru. Guru tidak lagi membatasi peserta didik dengan hal-hal yang akan menghambat perkembangan potensinya dalam proses aktualisasi diri.

(5) Angin yang harus menunggal sehingga mengerti betul dengan aspirasi

Angin merupakan benda yang tak tampak, namun dapat dirasakan dan dapat menembus ruang melalui celah-celah sempit. Begitu pula dengan kemampuan guru untuk mampu menyusup pada diri peserta didik untuk membuat peserta didik nyaman ketika mengikuti proses kegiatan belajar mengajar. Kegiatan pembelajaran dapat dimulai dengan cara, guru menyampaikan tujuan dan fungsi dari pembelajaran dikelas (Helmiati, 2014). Ketika, peserta didik sudah memahami dari arah tujuan dan fungsi dari pembelajaran, maka peserta didik akan lebih termotivasi untuk mengikuti pembelajaran dikelas. Saat peserta didik merasa membutuhkan materi dalam pembelajaran, disaat itulah guru harus berperan tidak hanya sebagai penyalur ilmu akademik saja.Tetapi guru harus mampu menyampaikan pelajaran tentang nilai-nilai moral yang mampu meningkatkan kualitas pemahanan nilai moral peserta didik.

(6) Api yang menghangatkan suasana dan tegas Guru yang memiliki wibawa adalah guru yang mampu menciptakan suasana yang hangat dan memiliki ketegasan yang mampu menunjukkan mana yang benar dan yang salah. Perlakuan ketika guru di kelas dapat dilakukan dengan cara pendekatan sistem proses kelompok atau dinamika kelompk dengan cara meningkatkan dan memelihara kelompok kelas yang efektif dan produktif. Pendekatan kelompok yang digunakan oleh Wilford (dalam Hosnan, 2014), merupakan salah satu dari 8 pendekatan dalam operasional pengelolaan kelas yang terdiri dari: (1) pendekatan otoriter: menekankan pengawasan dan pengaturan peserta didik, (2) pendekatan intimidasi: memberikan peluang besar guru untuk mengawasi dan menerbitkan siswa dengan cara intimidasi, (3) pendekatan permisif: peserta didik mendapat kebebasan dan guru hanya mengawasi, (4) pendeakatan "Resep Masakan": menekankan guru untuk melihat dan mengawasi sejauh mana peserta didik mengikuti dengan tertib dan tepat halhal yang sudah ditentukan, apa yang boleh dan tidak boleh, (5) pendekatan pengajaran: guru menyusun rencana pembelajaran sehingga dapat menghindari perihal yang tidak diinginkan, (6) pendekatan modifikasi perilaku: guru mengupayakan perubahan perilaku positif peserta didik, (7) pendekatan Iklim Sosio-emosional: guru menekankan pada terjalinnya hubungan yang positif antara guru dan peserta didik. Ketika berbicara tentang pendekatan, maka terdapat perlakuan guru yang akan mengikat peserta didik untuk mengikuti aturan dan disinilah ketegasan akan terwujud. Tetapi selama proses peserta didik tidak akan merasa terbebani. Karena 
aturan yang dibuat merupakat kesepakatn bersama.

(7) Samudra yang harus bijaksana dan menyejukkan.

Ketika berada di sekolah, peserta didik membutuhkan sosok yang bijaksana dan mampu memberikan kesejukan hati bagi peserta didik.Seperti samudra yang luas, yang mampu menampung seluruh peserta didik untuk turut andil menikmati peran guru yang bijaksana dalam menyikapi setiap persoalan atau peristiwa yang terjadi di sekolah. Sehingga, saat disekolah peserta didik akan merasakan ketenangan dan kenyamanan.

(8) Tanah yang harus bersikap teguh, murah hati, dan suka beramal.

Tanah merupakan media bagi tanaman yang tidak memperhitungkan berapa banyak tanaman yang tumbuh dengan menyedot unsure-unsur kesuburan dari tanah. Seperti itu pula guru yang tidak akan pernah menghitung berapa banyak ilmu yang diberikan. Tetapi guru mebagikan ilmunya, hanya sebagai ladang amal yang memberikan kemanfaatan.

\section{Guru sebagai Role Model}

Guru dapat dikatakan sebagai role model, jika guru tersebut mampu melaksanakan tugasnya dengan cara yang baik dan betul, sehingga menjadi panutan bagi peserta didiknya. Salah satu tokoh acuan peserta didik dalam berperilaku adalah guru. Guru hendaknya bertindak sebagai role model, suri teladan bagi kehidupan sosial akademis siswa, baik di dalam maupun di luar kelas (Mas'ud, 2003). Jelas disini peranan guru bukan saja dilihat dari ilmunya, tetapi juga dilihat dari sikap, perangainya dan proses berfikir ketika mengajar (Arends, 2013). Untuk menjadi role model yang baik, perlu diperhatikan adalah mempunyai pribadi yang baik, ini termasuk cara berbahasa, cara berhubungan, tingkah laku, tata susila yang tinggi, baik hati, ramah, bisa dipercaya, berpendirian teguh, iklas dalam mengajar, cara bertindak yang mengarah kepada siakap positif dan sebagainya.

Peranan guru sebagai model dapat dijelaskan dalam sebuah bagan dibawah ini. (Mradzuam, 2009)

Bagan 1. Guru sebagai role model



a. Guru harus mempunyai pengetahuan yang luas terhadap peserta didik.

Guru hendaknya mempunyai pengetahuan yang luas di luar dari pengajaran. Dalam hal ini guru hendaknya memiliki banyak kebolehan dalam mengadakan variasi dalam pembelajaran, sehingga peserta didik tidak merasa jenuh dan menimbulkan kekaguman terhadap seorang guru.Dalam meningkatkan pengetahuannya guru harus bersikap kreatif dan imajinatif, serta selalu mengadakan percobaan, pengkajian, penyelidikan dan sebagainya. Sehingga peserta didik akan terkagum-kagum dan akan menjadikan guru tersebut sebagai contoh dalam hidupnya, ketika peserta didik dituntut untuk selalu berkreasi. Guru juga harus bisa menguasi dan mengikuti perkembangan teknolagi, sebagai pendukung dalam proses belajar mengajar. Demikian, pendayagunaan teknologi banyak mewarnai pendidikan, baik dalam perencanaan, pelaksanaan, maupun monitoring dan evaluasi; dengan tujuan 
untuk meningkatkan kualitas pendidikan; agar bisa bersaing, bersanding, dan bertanding dengan Negara-negara lain dalam perspektif global (Mulyasa, 2014).

b. Guru hendaknya memiliki sifat kepemimpinan

Sifat kepemimpinan seorang guru dapat dilihat dari bagaimana seorang guru mampu membimbing, mengajar, menggerakkan serta mempengaruhui peserta didik baik secara individu maupun secara berkelompok. Kemampuan atau teknik dalam mempengaruhi atau menggerakkan peserta didik dalam manajemen pembelajaran, yaitu menuntut seorang guru untuk mengembangkan seluruh pribadi peserta didik dalam menyelesaikan permasalahan pembelajaran untuk mencapai tujuan pembelajaran secara efektif dan efisien (Mulyasa : 2014). Kepemimpinan guru juga ditunjukkan juga dengan bagaimana guru sebagai role model dalam membentuk peserta didik menjadi pribadi yang bertanggung jawab, jujur, dapat dipercaya dan berakhak mulia. Guru sebagai seorang pemimpin hendaknya mampu melakukan pekerjaannya dengan baik, sistematis, bertanggung jawab dan teratur, sehingga dapat menarik perhatiaan peserta didik, sehingga peserta didik akan tertarik untuk mengikutinya. Aspek kepemimpinan guru juga dalam hal selalu memberikan nasehat dan motivasi yang positif kepada peserta didiknya, sehingga peserta didik tergerak atau termotivasi untuk selalu melakukan hal-hal yang berguna untuk masa depannya.

c. Guru diharapkan mempunyai emosi yang stabil

Dalam kegiatan belajar mengajar tak jarang guru sering menjumpai suatu permasalahan yang melibatkan sikap dan peranggai peserta didik yang kurang baik, sehingga menguji kesabaran seorang guru. Disinilah seorang guru harus bisa mengendalikan emosinya, dan mampu bersikap bijak kepada semua permasalahan yang ada di dalam proses belajar mengajar. Seorang guru harus juga mempunyai kecerdasan emosi agar seseorang mampu menjalin hubungan baik dengan orang lain, menanamkan rasa empati, juga bagaimana cara mengalahkan emosi dengan cara memotivasi diri (Azhari, 2004). Kesabaran, bijak sana dalam mengambil keputusan, serta tidak berat sebelah sangat diperlukan ketika seorang guru menyelesaikan permasalahan yang berhubungan dengan siswa. Dengan sifat guru yan selalu stabil dalam emosinya, maka peserta didik akan merasa nyaman dan senang belajar di lingkungan sekolah tersebut, serta tidak akan ragu-ragu atau segan meminta bantuan kepada gurunya, jika mereka sedang mengalami kesulitan dalam proses belajar.

d. Guru hendaknya mempunyai peran dalam pembentukan watak peserta didik

Pendidikan di sekolah secara tidak langsung mempunyai peran yang cukup besar dalam pembentukan watak seorang peserta didik.Maka disini peran seorang guru sebagai role model sangat diperlukan. Pengaruh kepribadian guru dalam mengajar sangat besar, dalam pembentukan watak peserta didik, sehingga guru harus menjadi suri tauladan yang baik dalam menjalankan tugasnya, bertanggung jawab, suka menolong, memberi bantuan tanpa pamrih, tidak melakukan kekerasan kepada peserta didiknya, memberikan penghargaan yang mengarah kepada hal-hal yang positif atas kerja keras peserta didiknya agar lebih termotivasi untuk berprestasi. Guru juga harus mengetahui perkembangan peserta didiknya serta membentuk peserta didik untuk menjadi insan yang bermartabat yang berguna bagi lingkungan sekolah, sosial maupun Negara.

e. Guru mempunyai andil dalam pembentukan karakter

Sebagai role model, guru harus mampu membentuk peserta didik menjadi pribadi yang betanggung jawab, berguna untuk diri sendiri dan masyarakat, mampu bersaing, jujur, cakap, mandiri dan pantang menyerah. Menurut Mendikbud, Muhammad Nuh, pembentukan pribadi atau karakter peserta didik perlu dilakukan sejak usia dini. Jika karakter sudah terbentuk usia dini, maka tidak akan mudah untuk 
mengubah karakter seseorang (Husaini, 2010). Jadi Pembentukan sikap atau karakter di mulai dari jenjang SD sampai perguruan tinggi.Oleh karena itu guru merupakan orang yang sangat penting dalam membina dan membangun pribadi peserta didiknya, agar berguna kelak dimasyarakat.Selain itu, guru juga harus dapat memberikan contoh kepada peserta didiknya untuk menciptakan suasana yang harmonis antara sesama peserta didik agar terciptanya linkungan belajar yang menyenangkan.

f. Guru mampu mengembangkan sikap sosial. Membangun sikap sosial peserta didik dapat dilakukan dengan berbagai cara, antara lain: membuat kesan pertama menyenangkan; memahami peserta didik; mempengaruhui peserta didik; membangun komunikasi yang efektif; hadiah dan hukuman yang efektif; memanusiakan peserta didik; menghindari perdebatan; mengembangkan rasa percaya diri; menciptakan lingkungan yang kondusif; dan dengan memanfaatkan kecerdasan emosional (Mulyasa, 2014). Dalam hal ini guru harus mampu mengajarkan peserta didik untuk dapat berinteraksi dengan lingkungannya dengan baik dan terarah. Untuk memudahkan terjadi sosialisasi dalam pendidikan, maka guru perlu menciptakan situasi, terutama pada dirinya sendiri, agar faktor-faktor yang mendasari sosialisasi itu muncul pada diri peserta didik (Pidarta: 2009). Dalam hal ini guru harus bisa menjadi role model dalam berprilaku agar ditiru, diidentifikasi, dan peserta didik merasa bersimpati kepadanya.Begitu juga dengan kondisi kelas, perlu dibina agar sosialisasi peserta didik tidak terhambat. Contoh yang riil tentang bagaimana cara berinteraksi dengan lingkungannya, yaitu mengadakan perayaan hari besar keagamaan, berbincangbincang dengan peserta didik tentang suatu permasalahan tentang pelajaran, mengadakan study tour, dan membuat suatu permainan. Secara tidak langsung contohcontoh diatas mengajarkan mereka untuk berani berinteraksi dengan lingkungannya dengan baik.Selain itu guru harus bisa menjadi teman bagi peserta didiknya, serta dapat menjalin suatu hubungan yang harmonis dengan sesama guru dan lingkungan masyarakat, sehingga dapat dijadikan contoh yang baik oleh peserta didik.

\section{KESIMPULAN}

Perilaku menyimpang yang di lakukan oleh peserta didik yang ada di lingkungan sekolah dapat di tangani oleh seorang guru dengan menggunakan strategi role model, dimana seorang guru mampu melaksanakan tugasnya dengan cara yang baik dan betul, sehingga menjadi panutan bagi peserta didiknya. Peranan guru sebagai model dan pendidik harus mempunyai pengetahuan yang luas, sifat kepemimpinan, emosional yang stabil, pembentukan watak, pembentukan karakter dan mengembangkan sikap sosial. Untuk menjadi seorang pendidik dan role model yang baik, perlu diperhatikan adalah mempunyai pribadi yang baik, ini termasuk cara berbahasa, cara berhubungan, tingkah laku, tata susila yang tinggi, baik hati, ramah, bisa dipercaya, berpendirian teguh, iklas dalam mengajar, cara bertindak yang mengarah kepada sikap positif dan sebagainya. Diharapkan dari guru sebagai role model dapat membentuk peserta didik untuk menjadi insan yang bermartabat yang berguna bagi lingkungan sekolah, sosial maupun Negara.

\section{SARAN}

Sebelum menetapkan strategi guru sebagai role model harus memperhatikan beberapa faktor, antara lain:

1. Guru harus mempunyai pengetahuan yang luas serta mau mengembangkan potensi dirinya dengan selalu membuka diri dengan hal-hal yang baru dan mau mempelajarinya, mengobservasi, mengkaji serta mengaplikasikannya kepada peserta didik.

2. Sarana dan prasarana IT yang tersedia pendidikan di sekolah kurang memadai.

3. Kesiapan dari pengajar dalam menyampaian materi dan membimbing siswa, sehingga pengajaran terlaksana scara terstruktur.

\section{DAFTAR RUJUKAN}

Aqib, Z. 2010. Menjadi Guru Profesional Berstandar Nasional. Bandung: Yrama Widya. 
Azhari, A. 2004.Psikologi Umum \& Perkembangan. Jakarta: PT. Mizan Publika.

DePorter, B., Nourie, S.S., dan Reardo, M. 2000.Quantum Teaching. Bandung: PT Mizan Pustaka.

Djiwandono, S.E. Wuryani. 2004. Psikologi Pendidikan. Jakarta: PT Gramedia.

Feist, J. dan Feist, G. J. 2012. Teori Kepribadian. Jakarta: Salemba Humanika.

Helmiati. 2014. Micro Teaching: Melatih Keterampilan Dasar Mengajar. Yogyakarta: Aswaja Pressindo.
Hosnan.2014. Pendekatan Saintifik dan Kontekstual dalam Pembelajaran Abad 21. Bogor: Ghalia Indonesia.

Lickona, T. 2012. Educating for Character. Jakarta: PT Bumi Aksara.

Mradzuan. 2009. Guru sebagai Role Model. http://www.scribd.com/21796644/ Guru.sebagai-role-model, diakses 22 Desember 2016.

Mulyasa, E. 2013.Guru dalam Implemantasi Kurikulum 2013.Bandung: PT Remaja Rosdakarya.

Pidarta, M. 2009. Landasan Kependidikan. Jakarta: PT. Rineka Cipta. 